\title{
Mild and efficient cyanuric chloride catalyzed Pictet-Spengler reaction
}

\author{
Ashish Sharma, Mrityunjay Singh, Nitya Nand Rai and Devesh Sawant ${ }^{*}$
}

\section{Full Research Paper}

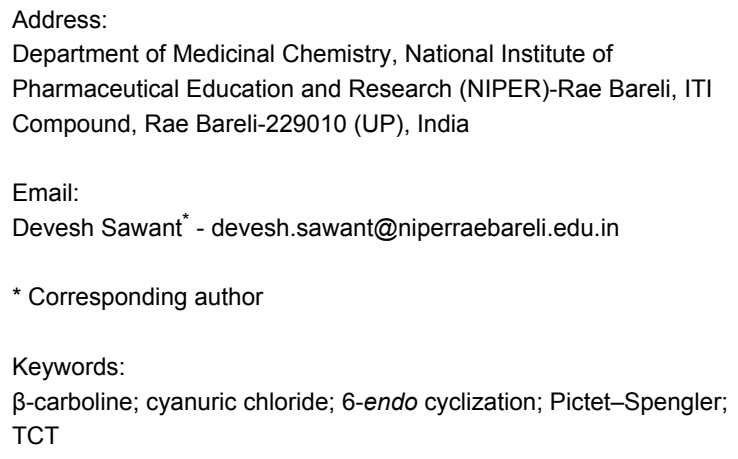

\author{
Beilstein J. Org. Chem. 2013, 9, 1235-1242. \\ doi:10.3762/bjoc. 9.140 \\ Received: 20 March 2013 \\ Accepted: 07 June 2013 \\ Published: 26 June 2013 \\ NIPER-RBL communication No. 001 \\ Associate Editor: T. J. J. Müller \\ (C) 2013 Sharma et al; licensee Beilstein-Institut. \\ License and terms: see end of document.
}

\begin{abstract}
A practical, mild and efficient protocol for the Pictet-Spengler reaction catalyzed by cyanuric chloride (trichloro-1,3,5-triazine, TCT) is described. The 6-endo cyclization of tryptophan/tryptamine and modified Pictet-Spengler substrates with both electronwithdrawing and electron-donating aldehydes was carried out by using a catalytic amount of TCT (10 mol \%) in DMSO under a nitrogen atmosphere. TCT catalyzed the Pictet-Spengler reaction involving electron-donating aldehydes in excellent yield. Thus, it has a distinct advantage over the existing methodologies where electron-donating aldehydes failed to undergo 6-endo cyclization. Our methodology provided broad substrate scope and diversity. This is indeed the first report of the use of TCT as a catalyst for the Pictet-Spengler reaction.
\end{abstract}

\section{Introduction}

The Pictet-Spengler reaction is an important class of name reaction employed extensively for the synthesis of tetrahydro- $\beta$ carboline [1-9]. Typically, the Pictet-Spengler reaction is a twostep reaction. The first step is the condensation of aliphatic amine substrates such as tryptophan/tryptamine and aldehydes to generate the intermediate imine in situ. The intermediate imine then undergoes a 6-endo cyclization to furnish the cyclized product, tetrahydro- $\beta$-carboline [10]. Recently, arylamines have been employed instead of the aliphatic amines for the Pictet-Spengler reaction. These reactions are generally termed as modified Pictet-Spengler reaction [11]. This modifi- cation of the conventional reaction led to the synthesis of a polyheterocyclic skeleton that mimics the natural products [1217]. The 6-endo cyclization is the rate-limiting step in the Pictet-Spengler reaction and electrophilicity of the imine is the driving force of the reaction [1]. The Pictet-Spengler reaction is catalyzed by Brønsted acids, as they convert the intermediate imine to the corresponding iminium ion, thus making it more electrophilic [18-22]. Conventionally, TFA [18], $\mathrm{HCl}$ [20], $\mathrm{H}_{2} \mathrm{SO}_{4}$ [21] and $p$-TsOH [22] are employed as Brønsted acids. However, recently several other aprotic or Lewis acids, such as $\mathrm{Yb}(\mathrm{OTf})_{3}$ [23-25], $\mathrm{AuCl}_{3} / \mathrm{AgOTf}[26], \mathrm{Me}_{3} \mathrm{SiCl}[27,28]$, 
$\mathrm{BF}_{3} \cdot \mathrm{Et}_{2} \mathrm{O}$ [29], iodine [30], zeolite [31] and enzymes [32-34], have been used for carrying out the Pictet-Spengler reaction.

Though the Pictet-Spengler reaction has been studied extensively under a variety of Brønsted/Lewis acid catalyzed conditions [35], most of these conditions failed to facilitate a 6-endo cyclization where salicylaldehyde (or any electron-donating aldehyde such as 4-dimethylaminobenzaldehyde) was used as a source of aldehyde [1,22]. Even harsher reaction conditions such as heating at a high temperature furnished the completely oxidized product, $\beta$-carboline [1]. The reason for this failure could be attributed to the reduced electrophilicity of the corresponding imine generated from these aldehydes. As a result of its reduced electrophilicity the imine failed to cyclize under the conditions reported earlier. A literature search revealed that the acyliminium strategy has been used to overcome this defect $[25,36,37]$. However, one has to cleave the $N$-acyl group of the product in order to generate the desired compound, and thus, an additional deprotection step has to be introduced. Instead, a mild and efficient catalyst that can effectively produce iminium species in situ could generate the compound of interest without adding any extra steps. We envisaged that the use of cyanuric chloride (2,4,6-trichloro-1,3,5-triazine, TCT) [38-45] as a source of $\mathrm{HCl}$ could trigger the 6-endo cyclization under dry and mild conditions. TCT is used in many reactions as a source of anhydrous $\mathrm{HCl}$ in organic synthesis [46]. Moreover, it is an attractive reagent due to its easy availability and low cost. It is well documented in the literature that TCT reacts with the incipient moisture and produces three moles of $\mathrm{HCl}$ and cyanuric acid as a byproduct [46]. The latter can be removed by a simple aqueous workup. Interestingly, this reagent has not been explored for the Pictet-Spengler reaction yet. Here we report the use of cyanuric chloride as a simple, inexpensive and efficient catalyst for the Pictet-Spengler reaction.

\section{Results and Discussion}

We began our studies by reacting tryptamine (1) and 4-tolualdehyde (2a) in the presence of $20 \mathrm{~mol} \%$ TCT in ethanol (Scheme 1). The reaction showed the formation of the cyclized product 3a albeit with the presence of starting materials even after prolonged heating $(16 \mathrm{~h})$. Encouraged by this initial obser- vation, we focused our attention on optimizing the reaction conditions. First, various solvents were examined. These findings are reported in Table 1. In general, the reaction proceeded well in polar solvents such as EtOH, acetonitrile and DMSO. In contrast, the reaction failed to produce the desired compounds, when nonpolar solvents such as toluene, DCM, dioxane and THF were used [47]. DMSO produced the best results, even though fully aromatized $\beta$-carboline was obtained as a side product. This drawback can be excluded by employing an inert atmosphere. Thus, reactions carried out in DMSO at $100{ }^{\circ} \mathrm{C}$ by using $20 \mathrm{~mol} \%$ TCT under nitrogen (Table 1, entry 8) demonstrated the best results. Next, we examined the amount of TCT needed for the cyclization and $20 \mathrm{~mol} \%$ of TCT was found to be optimal for the reaction. An increase of the catalytic loading led to the appearance of side products on a TLC. Reaction temperature was found to be optimal at $100{ }^{\circ} \mathrm{C}$, since a lower temperature $\left(50\right.$ to $\left.80^{\circ} \mathrm{C}\right)$ required longer reaction time $(48 \mathrm{~h})$ for the completion, and a higher temperature (beyond $120^{\circ} \mathrm{C}$ ) produced undesired side products [48].

Once we had identified the optimized reaction conditions, we scrutinized the substrate scope and limitation of the TCTcatalyzed Pictet-Spengler reaction. We explored two different

\begin{tabular}{|c|c|c|c|c|c|}
\hline Entry & Solvent & $\begin{array}{c}\text { Temp. } \\
\left({ }^{\circ} \mathrm{C}\right)\end{array}$ & $\begin{array}{c}\text { TCT } \\
(\mathrm{mol} \%)\end{array}$ & $\begin{array}{l}\text { Time } \\
\text { (h) }\end{array}$ & $\begin{array}{l}\text { Isolated } \\
\text { yield (\%) }\end{array}$ \\
\hline 1 & $\mathrm{EtOH}$ & 85 & 20 & 16 & $61^{a}$ \\
\hline 2 & acetonitrile & 85 & 20 & 16 & $75^{a}$ \\
\hline 3 & toluene & 110 & 20 & 16 & $N R^{b}$ \\
\hline 4 & DMSO & 100 & 5 & 16 & 45 \\
\hline 5 & DMSO & 100 & 10 & 16 & 68 \\
\hline 6 & DMSO & 100 & 20 & 4 & $85^{c}$ \\
\hline 7 & DMSO & 100 & 30 & 8 & $78^{d}$ \\
\hline 8 & $\mathrm{DMSO} / \mathrm{N}_{2}$ & 100 & 20 & 8 & 92 \\
\hline
\end{tabular}

astarting material recovered, ${ }^{b}$ an intermediate imine observed as the major product, cfully aromatic $\beta$-carboline observed as a side product

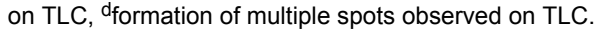


Pictet-Spengler substrates for the TCT-catalyzed reaction as depicted in Figure 1. Tryptamine (1) was commercially available, while substrate 4 was synthesized from the nucleophilic substitution of indole (5) with 2-fluoronitrobenzene (6) to generate intermediate 7 , which was reduced to amine 4 by $\mathrm{Zn} / \mathrm{HCl}$ (Scheme 2).

Both substrates reacted with benzaldehyde derivatives and results are summarized in Table 2. Tryptamine (1) reacted well with aldehydes with both electron-donating and electron-withdrawing substituents to furnish 1,2,3,4-tetrahydro- $\beta$-carboline 3 . It is interesting to note that salicylaldehyde (2g) and 4-dimethylaminobenzaldehyde $(\mathbf{2 h})$ produced the desired cyclized products $\mathbf{3 g}$ and $\mathbf{3 h}$, respectively, when condensed with tryptamine (1) in the presence of cyanuric chloride. It is reported in the literature that the condensation of electron-donating aldehydes,<smiles>NCCc1c[nH]c2ccccc12</smiles><smiles>Cc1ccc(-n2ccc3ccccc32)c(N)c1</smiles>

indole-based modified substrate

Figure 1: The two Pictet-Spengler substrates employed in the TCT catalyzed cyclization.

such as salicylaldehyde with tryptophan methyl ester or tryptamine in acidic media, provided the 6-endo cyclized product in poor yield along with impurities $[1,22]$. In contrast, our methodology proved effective in catalyzing the condensation of trypta-<smiles>Nc1ccccc1-n1ccc2ccccc21</smiles>

5

6

7

4

Scheme 2: Synthesis of the Pictet-Spengler substrate 4. Reaction conditions: (a) $\mathrm{K}_{2} \mathrm{CO}_{3}, \mathrm{DMF}, 80{ }^{\circ} \mathrm{C}, 3 \mathrm{~h}$; (b) $\mathrm{Zn}, \mathrm{AcOH}-\mathrm{EtOH}, 60{ }^{\circ} \mathrm{C}, 4 \mathrm{~h}$.

Table 2: Condensation of the Pictet-Spengler substrates 1 and 4 (1 equiv) with aldehyde (1 equiv) in the presence of TCT (20 mol \%) in DMSO under a nitrogen atmosphere.

\begin{tabular}{|c|c|c|c|c|c|c|c|c|}
\hline Entry & Substrate & Aldehyde & Product & $\begin{array}{c}\text { Time } \\
\text { (h) }\end{array}$ & $\begin{array}{c}\text { Yield } \\
(\%)\end{array}$ & $\begin{array}{l}\mathrm{mp} \\
\left({ }^{\circ} \mathrm{C}\right)\end{array}$ & $\begin{array}{l}\text { Lit. mp } \\
\left({ }^{\circ} \mathrm{C}\right)\end{array}$ & $\begin{array}{c}\text { ESI: } m / z \\
(\%)\end{array}$ \\
\hline
\end{tabular}

1 1<smiles>Cc1ccc(C=O)cc1</smiles>

$2 a$<smiles>Cc1ccc(C2NCCc3c2[nH]c2ccccc32)cc1</smiles>

$3 a$<smiles>Brc1ccccc1C1NCCc2c1[nH]c1ccccc21</smiles>

$3 b$<smiles>O=Cc1ccccc1Br</smiles>

$2 b$<smiles>O=Cc1ccc([N+](=O)[O-])cc1</smiles>

2c<smiles>O=[N+]([O-])c1ccc(C2NCCc3c2[nH]c2ccccc32)cc1</smiles>

$3 c$
3 92 138-139 135-137 [19] $263\left[\mathrm{M}+\mathrm{H}^{+}, 100\right]$

4

83

$155-157$

-a $[49]$

$\left.\mathrm{M}+\mathrm{H}^{+}, 100\right]$

$329\left[\mathrm{M}+\mathrm{H}^{+}, 97\right]$

2

$95 \quad 169-171 \quad 170-171[50] \quad 294\left[\mathrm{M}+\mathrm{H}^{+}, 100\right]$ 
Table 2: Condensation of the Pictet-Spengler substrates 1 and 4 (1 equiv) with aldehyde (1 equiv) in the presence of TCT (20 mol \%) in DMSO under a nitrogen atmosphere. (continued)

5<smiles>O=Cc1ccccc1O</smiles>

$2 \mathrm{~g}$<smiles>O=Cc1ccccc1[N+](=O)[O-]</smiles>

$2 f$<smiles>O=[N+]([O-])c1ccccc1C1NCCc2c1[nH]c1ccccc21</smiles><smiles>Oc1ccccc1C1NCCc2c1[nH]c1ccccc21</smiles>

$3 g$<smiles>CN(C)c1ccc(C=O)cc1</smiles>

$2 \mathrm{~h}$<smiles>CN(C)c1ccc(C2NCCc3c2[nH]c2ccccc32)cc1</smiles>

$3 \mathrm{~h}$<smiles>O=Cc1ccc([N+](=O)[O-])cc1</smiles>

2a<smiles>O=Cc1ccc([N+](=O)[O-])cc1</smiles><smiles>Cc1ccc(-c2nc3ccccc3n3c2cc2ccccc23)cc1</smiles>

$8 a$<smiles>O=[N+]([O-])c1ccc(-c2nc3ccccc3n3c2cc2ccccc23)cc1</smiles>

5 $92 \quad 205-206 \quad 207-208[50] \quad 283\left[\mathrm{M}+\mathrm{H}^{+}, 100\right]$

6 $85 \quad 191-193 \quad-{ }^{b}[51] \quad 279\left[\mathrm{M}+\mathrm{H}^{+}, 100\right]$ $3 \quad 88 \quad 151-152 \quad-^{c}[52] \quad 294\left[M+H^{+}, 100\right]$ 4 $84 \quad 190-191 \quad 189-191[19] \quad 265\left[\mathrm{M}+\mathrm{H}^{+}, 100\right]$

$6 \quad 79 \quad 231-233 \quad 235-237[53] \quad 292\left[\mathrm{M}+\mathrm{H}^{+}, 100\right]$

2 $91 \quad 160-162 \quad 309\left[\mathrm{M}+\mathrm{H}^{+}, 100\right]$

8b 
Table 2: Condensation of the Pictet-Spengler substrates 1 and 4 (1 equiv) with aldehyde (1 equiv) in the presence of TCT (20 mol \%) in DMSO under a nitrogen atmosphere. (continued)

11

4<smiles>O=Cc1ccc(Cl)cc1</smiles>

2d<smiles>Clc1ccc(-c2nc3ccccc3n3c2cc2ccccc23)cc1</smiles>

$8 c$

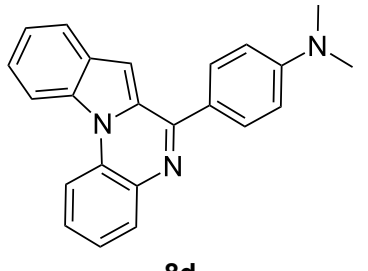

2 95 205-207 $329\left[\mathrm{M}+\mathrm{H}^{+}, 100\right]$
85
146-147 145-147 [12] $338\left[\mathrm{M}+\mathrm{H}^{+}, 100\right]$

8d

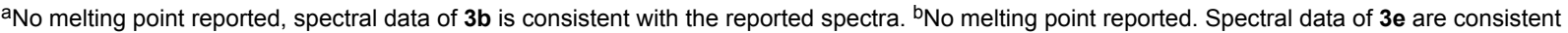
with the reported spectra. ${ }^{\mathrm{C}}$ No physical and spectral data are reported.

mine and electron-donating aldehydes. Interestingly, the orthosubstitution on benzaldehyde is also well tolerated. For instance, the condensation of 2-bromobenzaldehyde $(\mathbf{2} \mathbf{b})$ or 2-nitrobenzaldehyde (2f) with tryptamine in the presence of TCT furnished the title compounds $\mathbf{3 b}$ or $\mathbf{3 f}$, respectively, in excellent yield.

The Pictet-Spengler reaction is a two-step process, where an aldehyde and an amine first react to give an imine as an intermediate. This is followed by a 6-endo intramolecular cyclization of the imine to produce the cyclized product. The second step is the rate-limiting step and the electrophilicity of the imine is the driving force of the cyclization. $\mathrm{HCl}$ generated in situ from TCT protonated the imine intermediate to an iminium ion, which undergoes a cyclization. The presence of an inert nitrogen atmosphere abated formation of the oxidized product ( $\beta$-carboline), thus allowing for a clean reaction. In a nutshell, the Pictet-Spengler reaction of tryptamine can be elegantly catalyzed by TCT with a high substrate scope and diversity, hence TCT proved to be a robust catalyst in the 6-endo cyclization.

Recently, the Pictet-Spengler reaction has been successfully extended to arylamine substrates [11-17]. These substrates are designed by replacing the aliphatic amine side chain attached to activated heterocycles, for example tryptamine (1), by aromatic amines [11]. Moreover, the aromatic amines can be originated from either carbon or nitrogen of the activated heterocycle. Hence, these substrates are referred to as "modified Pictet-Spengler substrates". We employed one of the arylamine substrates for our studies (Figure 1). In substrate 4 (Figure 1), the aromatic amine side chain originates from the $N-1$ of indole. It was subjected to the TCT catalyzed Pictet-Spengler reaction with benzaldehyde derivatives. The results are summarized in Table 2.

The substrate 4 reacted equally well with both electron-donating as well as electron-withdrawing aldehydes to yield the 6-endo product indolo[1,2-a]quinoxalines 8 (Table 2). It is interesting to note that the cyclized products of the modified Pictet-Spengler substrate $\mathbf{4}$ are fully aromatized. This is probably because the cyclized dihydro derivatives formed in situ are prone to oxidation. Substrate 4 furnished the cyclized product faster compared to tryptamine (1). This might be attributed to the enhanced electrophilicity of the imine derived from the arylamine compared to the aliphatic amine as reported earlier [16].

The TCT catalyzed condensation of the Pictet-Spengler substrates 1 and $\mathbf{4}$ with aldehydes furnished tetrahydro- $\beta$-carboline 3 and indolo[1,2-a]quinoxaline 8 , respectively. The $\beta$-carboline skeleton is widely distributed in marine organisms [54-56]. Eudistomine and manzamine isolated from marine invertebrates exhibited promising anticancer activity [57,58]. Tedalafil, a drug based on the tetrahydro- $\beta$-carboline skeleton, is widely used to treat erectile dysfunction [59]. Hence, these nuclei constitute an important class of heterocyclic compounds, which posses a wide range of pharmacological properties.

\section{Conclusion}

Here we disclosed the first report of the Pictet-Spengler reaction catalyzed by cyanuric acid. Both conventional and modi- 
fied Pictet-Spengler substrates reacted equally well with electron-donating and electron-withdrawing aldehydes. TCT proved effective in catalyzing the 6-endo cyclization of aldehydes such as salicylaldehyde and 4-dimethylaminobenzaldehyde. These aldehydes failed to produce the cyclized product in desired yield under conventional Brønsted acid catalysis and often produced the oxidized products under harsher reaction conditions. TCT under an inert atmosphere allowed for a clean reaction with a broad substrate scope and application. We demonstrated application of this methodology for the synthesis of tetrahydro- $\beta$-carbolines 3 and indolo[1,2- $a]$ quinoxalines 8 . These scaffolds are present in numerous biologically active compounds. Nevertheless, TCT is inexpensive and readily available. Therefore, this methodology can be easily employed in the synthesis of a spectrum of pharmacologically active compounds on multigram to industrial scales.

\section{Experimental}

A typical experimental procedure: Cyanuric chloride (10 mol \%) was added to the mixture of tryptamine (1) or arylamine substrate $4(1 \mathrm{mmol})$ and aldehyde $\mathbf{2}(1 \mathrm{mmol})$ in DMSO at $\mathrm{rt}$ under a nitrogen atmosphere. The resultant mixture was warmed at $100{ }^{\circ} \mathrm{C}$ and stirred for $8 \mathrm{~h}$. The reaction mixture was poured on the bed of crushed ice to obtain the crude. The solid so obtained was filtered and washed with chilled water and $10 \%$ EtOAc/hexane solution to remove water-soluble side products and excess aldehydes. Wherever needed the crude was further purified either by recrystallization in EtOH or by flash chromatography.

1-(4-Methylphenyl)-2,3,4,9-tetrahydro-1 $\mathrm{H}$-pyrido[3,4b]indole (3a): Yield 92\%; pale-yellow solid; mp $138-139{ }^{\circ} \mathrm{C}$; ${ }^{1} \mathrm{H}$ NMR $\left(\mathrm{CDCl}_{3}, 300 \mathrm{MHz}\right) \delta 7.94$ (br s, $\left.1 \mathrm{H}\right), 7.60-7.57$ (m, $1 \mathrm{H}), 7.18-7.13(\mathrm{~m}, 7 \mathrm{H}), 5.10(\mathrm{~s}, 1 \mathrm{H}), 3.39-3.32(\mathrm{~m}, 1 \mathrm{H})$, $3.17-3.08(\mathrm{~m}, 1 \mathrm{H}), 2.99-2.84(\mathrm{~m}, 2 \mathrm{H}), 2.39(\mathrm{~s}, 3 \mathrm{H}) ;{ }^{13} \mathrm{C} \mathrm{NMR}$ $\left(\mathrm{CDCl}_{3}, 75.5 \mathrm{MHz}\right) \delta 138.91,138.05,136.00,134.81,129.57$, 128.57, 127.50, 121.73, 119.42, 118.29, 110.97, 110.15, 57.85, 42.86, 22.63, 21.29, IR (KBr): 3426, 3309, 2924, 2852, 1595 $\mathrm{cm}^{-1}$; MS $\left(\mathrm{ES}^{+}\right) \mathrm{m} / z: 263.2[\mathrm{M}+\mathrm{H}]^{+}$.

$\mathrm{N}$-(4-Indolo[1,2-a]quinoxalin-6-ylphenyl)dimethylamine (8d): yield $85 \%$, yellow solid, mp $149-151{ }^{\circ} \mathrm{C} ;{ }^{1} \mathrm{H}$ NMR $\left(\mathrm{CDCl}_{3}, 300 \mathrm{MHz}\right) \delta 8.52(\mathrm{~d}, J=8.2 \mathrm{~Hz}, 1 \mathrm{H}), 8.07$ (dd, $J=1.2$, $7.9 \mathrm{~Hz}, 1 \mathrm{H}), 8.03(\mathrm{~d}, J=8.8 \mathrm{~Hz}, 2 \mathrm{H}), 7.96(\mathrm{~d}, J=7.8 \mathrm{~Hz}, 1 \mathrm{H})$ $7.75(\mathrm{~d}, J=8.9 \mathrm{~Hz}, 1 \mathrm{H}), 7.61-7.54(\mathrm{~m}, 2 \mathrm{H}), 7.45(\mathrm{t}, J=7.4 \mathrm{~Hz}$, 1H), 7.36 (s, 1H), 6.90 (d, $J=8.8 \mathrm{~Hz}, 2 \mathrm{H}), 6.72(\mathrm{~d}, J=8.8 \mathrm{~Hz}$, $1 \mathrm{H}), 3.10(\mathrm{~s}, 6 \mathrm{H}) ;{ }^{13} \mathrm{C} \mathrm{NMR}\left(75 \mathrm{MHz}, \mathrm{CDCl}_{3}\right) \delta 151.80$, 136.67, 133.02, 131.96, 130.11, 129.97, 129.87, 129.36, 129.33, $127.42,126.10,124.02,122.65,122.44,114.59,114.55,111.85$, 110.98, 102.37, 40.52; IR (KBr): 3020, 2924, $1599 \mathrm{~cm}^{-1}$; MS $\left(\mathrm{ES}^{+}\right) \mathrm{m} / \mathrm{z}: 338.3[\mathrm{M}+\mathrm{H}]^{+}$.

\section{Supporting Information}

\section{Supporting Information File 1}

Analytical data and copies of ${ }^{1} \mathrm{H}$ and ${ }^{13} \mathrm{C}$ NMR of $\mathbf{3 a}, \mathbf{3 c}$, 3h and $\mathbf{8 d}$.

[http://www.beilstein-journals.org/bjoc/content/ supplementary/1860-5397-9-140-S1.pdf]

\section{Acknowledgements}

The authors thank the Open Source Drug Discovery (OSDD) program of CSIR, New Delhi for funding as well as the Department of Pharmaceuticals, Ministry of Chemicals and Fertilizers, Government of India for granting a fellowship to A.S. and M.S. We are grateful to Dr. P. K. Shukla, Project Director NIPERRaeBareli, and Dr. B. Kundu, Dean, NIPER-RaeBareli for their support and motivation.

\section{References}

1. Cox, E. D.; Cook, J. M. Chem. Rev. 1995, 95, 1797-1842. doi:10.1021/cr00038a004 And references therein.

2. Nielsen, T. E.; Diness, F.; Meldal, M. Curr. Opin. Drug Discovery Dev. 2003, 6, 801-814.

3. Youn, S. W. Org. Prep. Proced. Int. 2006, 38, 505-591. doi:10.1080/00304940609356447

4. Royer, J.; Bonin, M.; Micouin, L. Chem. Rev. 2004, 104, 2311-2352. doi:10.1021/cr020083x

5. Larghi, E. L.; Amongero, M.; Bracca, A. B. J.; Kaufman, T. S. ARKIVOC 2005, 98-153. doi:10.3998/ark.5550190.0006.c09

6. Kaufman, T. S. Synthesis of opically-active isoquinoline and indolealkaloids employing the Pictet-Spengler condensation with removabiechiral auxiliaries bound to nitrogen. In New Methods in the Asymmetric Synthesis of Nitrogen Heterocycles; Vicario, J. L.; Badía, D.; Carrillo, L., Eds.; Research SignPost: Trivandrum, Kerala, India, 2005; pp $99 \mathrm{ff}$.

7. Whaley, W. M.; Govindachari, T. R. Org. React. 1951, 6, 151-190.

8. Abramovitch, R. A.; Spenser, I. D. Adv. Heterocycl. Chem. 1964, 3 , 79-207. doi:10.1016/S0065-2725(08)60542-5

9. Stuart, K.; Woo-Ming, R. Heterocycles 1975, 3, 223-264. doi:10.3987/R-1975-03-0223

10. Kowalski, P.; Bojarski, A. J.; Mokrosz, J. L. Tetrahedron 1995, 51 , 2737-2742. doi:10.1016/0040-4020(95)00022-Z

11. Kundu, B.; Agarwal, P. K.; Sharma, S. K.; Sawant, D.; Mandadapu, A. K.; Saifuddin, M.; Gupta, S. Curr. Org. Synth. 2012, 9, 357-376. doi:10.2174/157017912801270559 And references therein.

12. Agarwal, P. K.; Sawant, D.; Sharma, S.; Kundu, B. Eur. J. Org. Chem. 2009, 292-303. doi:10.1002/ejoc.200800929

13. Sharma, S.; Saha, B.; Sawant, D.; Kundu, B. J. Comb. Chem. 2007, 9 , 783-792. doi:10.1021/cc0700445

14. Che, X.; Zheng, L.; Dang, Q.; Bai, X. J. Org. Chem. 2008, 73, 1147-1149. doi:10.1021/jo7020746

15. Zheng, L.; Xiang, J.; Dang, Q.; Guo, S.; Bai, X. J. Comb. Chem. 2005, 7, 813-815. doi:10.1021/cc0500809 
16. Duggineni, S.; Sawant, D.; Saha, B.; Kundu, B. Tetrahedron 2006, 62, 3228-3241. doi:10.1016/j.tet.2006.01.063

17. Kundu, B.; Sawant, D.; Partani, P.; Kesarwani, A. P. J. Org. Chem. 2005, 70, 4889-4892. doi:10.1021/jo050384h

18. Grigg, R.; Gunaratne, H. Q. N.; McNaghten, E. J. Chem. Soc., Perkin Trans. 11983, 185-187. doi:10.1039/P19830000185

19. Saha, B.; Sharma, S.; Sawant, D.; Kundu, B. Tetrahedron Lett. 2007, 48, 1379-1383. doi:10.1016/j.tetlet.2006.12.112

20. Hahn, G.; Hansel, A. Ber. Dtsch. Chem. Ges. B 1938, 71, 2163-2175. doi:10.1002/cber.19380711024

21. Snyder, H. R.; Hansch, C. R.; Katz, L.; Parmerter, S. M.; Spaeth, E. C. J. Am. Chem. Soc. 1948, 70, 219-221. doi:10.1021/ja01181a063

22. Hamaguchi, F.; Nagasaka, T.; Ohki, S. Yakugaku Zasshi 1974, 94, 351-358.

23. Manabe, K.; Nobutou, D.; Kobayashi, S. Bioorg. Med. Chem. 2005, 13, 5154-5158. doi:10.1016/j.bmc.2005.05.018

24. Tsuji, R.; Yamanaka, M.; Nishida, A.; Nakagawa, M. Chem. Lett. 2002, 31, 428-429. doi:10.1246/cl.2002.428

25. Srinivasan, N.; Ganesan, A. Chem. Commun. 2003, 916-917. doi:10.1039/B212063A

Also demonstrated the use of Lewis acids for the Pictet-Spengler cyclization such as $\mathrm{AlCl}_{3}, \mathrm{TiCl}_{4}, \operatorname{lnCl}_{3}, \ln (\mathrm{OTf})_{3}, \mathrm{YbCl}_{3}, \mathrm{Sc}(\mathrm{OTf})_{3}$, $\mathrm{Ce}(\mathrm{OTf})_{3}$. Ionic liquid and microwave have also shown to facilitate cyclization.

26. Youn, S. W. J. Org. Chem. 2006, 71, 2521-2523. doi:10.1021/jo0524775

27. Tsuji, R.; Nakagawa, M.; Nishida, A. Tetrahedron: Asymmetry 2003, 14, 177-180. doi:10.1016/S0957-4166(02)00793-0

28. Kawate, T.; Nakagawa, M.; Ogata, K.; Hino, T. Heterocycles 1992, 33, 801-811. doi:10.3987/COM-91-S86

29. Silveira, C. C.; Vieira, A. S.; Kaufman, T. S. Tetrahedron Lett. 2006, 47, 7545-7549. doi:10.1016/j.tetlet.2006.08.097

30. Lingam, Y.; Rao, D. M.; Bhowmik, D. R.; Santu, P. S.; Rao, K. R.; Islam, A. Tetrahedron Lett. 2007, 48, 7243-7245. doi:10.1016/j.tetlet.2007.06.099

31. Hegedüs, A.; Hell, Z. Tetrahedron Lett. 2004, 45, 8553-8555. doi:10.1016/j.tetlet.2004.09.097

32. Kutchan, T. M. FEBS Lett. 1989, 257, 127-130. doi:10.1016/0014-5793(89)81802-2

33. Treimer, J. F.; Zenk, M. H. Eur. J. Biochem. 1979, 101, 225-233. doi:10.1111/j.1432-1033.1979.tb04235.x

34. Bernhardt, P.; McCoy, E.; O'Connor, S. E. Chem. Biol. 2007, 14, 888-897. doi:10.1016/j.chembiol.2007.07.008

35. Pictet, A.; Spengler, T. Ber. Dtsch. Chem. Ges. 1911, 44, 2030-2036. doi:10.1002/cber.19110440309

The Pictet-Spengler reaction was first discovered by Ame Pictet and Theodor Spengler in 1911.

36. Taylor, M. S.; Jacobsen, E. N. J. Am. Chem. Soc. 2004, 126, 10558-10559. doi:10.1021/ja046259p

37. Yu, J.; Wearing, X. Z.; Cook, J. M. Tetrahedron Lett. 2003, 44, 543-547. doi:10.1016/S0040-4039(02)02618-7

38. De Luca, L.; Giacomelli, G.; Porcheddu, A. Org. Lett. 2002, 4, 553-555. doi:10.1021/ol017168p

39. De Luca, L.; Giacomelli, G.; Porcheddu, A. J. Org. Chem. 2002, 67, 6272-6274. doi:10.1021/jo025960d

40. Kangani, C. O.; Day, B. W. Org. Lett. 2008, 10, 2645-2648. doi:10.1021/ol800752v

41. Das, B.; Kumar, R. A.; Thirupathi, P. Helv. Chim. Acta 2007, 90, 1206-1210. doi:10.1002/hlca.200790119
42. Blotny, G. Tetrahedron 2006, 62, 9507-9522. doi:10.1016/j.tet.2006.07.039

43. Sharma, G. V. M.; Reddy, J. J.; Lakshmi, P. S.; Krishna, P. R. Tetrahedron Lett. 2004, 45, 7729-7732. doi:10.1016/j.tetlet.2004.08.084

44. Sharma, M.; Pandey, S.; Chauhan, K.; Sharma, D.; Kumar, B.; Chauhan, P. M. S. J. Org. Chem. 2012, 77, 929-937. doi:10.1021/jo2020856

45. Maleki, M.; Azarifar, D.; Hojati, S. F.; Veisi, H.; Gholizadeh, M.; Salehabadi, H.; Moghadam, M. K. J. Heterocycl. Chem. 2011, 48, 449-453. doi:10.1002/jhet.462

46. Bigdeli, M. A.; Mahdavinia, G. H.; Jafari, S.; Hazarkhani, H. Catal. Commun. 2007, 8, 2229-2231. doi:10.1016/j.catcom.2007.05.010

47. No cyclized product formed even after prolonged heating under reflux for $24 \mathrm{~h}$ in the respective solvent system.

48. Tryptamine and 4-tolualdehyde was heated at $60{ }^{\circ} \mathrm{C}, 80{ }^{\circ} \mathrm{C}, 100{ }^{\circ} \mathrm{C}$, $120^{\circ} \mathrm{C}$ and $140{ }^{\circ} \mathrm{C}$ in DMSO in the presence of $20 \mathrm{~mol} \%$ TCT.

49. Klausen, R. S.; Jacobsen, E. N. Org. Lett. 2009, 11, 887-890. doi:10.1021/ol802887h

50. Prajapati, D.; Gohain, M. Synth. Commun. 2008, 38, 4426-4433. doi:10.1080/00397910802369547

51. Li, C.; Xiao, J. J. Am. Chem. Soc. 2008, 130, 13208-13209. doi:10.1021/ja8050958

52. Pal, B.; Jaisankar, P.; Giri, V. S. Synth. Commun. 2003, 33, 2339-2348. doi:10.1081/SCC-120021516

53. Shen, Y.-C.; Chen, C.-Y.; Hsieh, P.-W.; Duh, C.-Y.; Lin, Y.-M.; Ko, C.-L. Chem. Pharm. Bull. 2005, 53, 32-36. doi:10.1248/cpb.53.32

54. Blackman, A. J.; Matthews, D. J.; Narkowicz, C. K. J. Nat. Prod. 1987, 50, 494-496. doi:10.1021/np50051a026

55. Kearns, P. S.; Coll, J. C.; Rideout, J. A. J. Nat. Prod. 1995, 58, 1075-1076. doi:10.1021/np50121a014

56. Kobayashi, J.; Tsuda, M.; Kawasaki, N.; Sasaki, T.; Mikami, Y. J. Nat. Prod. 1994, 57, 1737-1740. doi:10.1021/np50114a021

57. Rinehart, K. L., Jr.; Kobayashi, J.; Harbour, G. C.; Gilmore, J.; Mascal, M.; Holt, T. G.; Shield, L. S.; Lafargue, F. J. Am. Chem. Soc. 1987, 109, 3378-3387. doi:10.1021/ja00245a031

58. Sakai, R.; Kohmoto, S.; Higa, T.; Jefford, C. W.; Bernardinelli, G. Tetrahedron Lett. 1987, 28, 5493-5496. doi:10.1016/S0040-4039(00)96762-5

59. Daugan, A.; Grondin, P.; Ruault, C.; Le Monnier de Gouville, A.-C.; Coste, H.; Kirilovsky, J.; Hyafil, F.; Labaudinière, R. J. Med. Chem. 2003, 46, 4525-4532. doi:10.1021/jm030056e 


\section{License and Terms}

This is an Open Access article under the terms of the Creative Commons Attribution License

(http://creativecommons.org/licenses/by/2.0), which permits unrestricted use, distribution, and reproduction in any medium, provided the original work is properly cited.

The license is subject to the Beilstein Journal of Organic Chemistry terms and conditions:

(http://www.beilstein-journals.org/bjoc)

The definitive version of this article is the electronic one which can be found at:

doi:10.3762/bjoc. 9.140 